\title{
PERILAKU PEJALAN KAKI TERHADAP PEMANFAATAN JALUR PEDESTRIAN DI KAWASAN PERDAGANGAN (Studi Kasus : Koridor Jalan Soeprapto Kota Gorontalo)
}

\author{
Fendy Faizal Gobel ${ }^{1}$ \\ ${ }^{1}$ Jurusan Arsitektur, Universitas Gorontalo
}

\begin{abstract}
This research aimed to analyze the pedestrian behavior toward the utilization of pedestrian ways at the commerce area at Soeprapto street corridor, Gorontalo city. This research was conducted directly at the place and time where the research being observed. There were two kinds of the behavioral mapping used in this research; those were Place Centered Mapping and Person Centered mapping.

The result of this research was showing that the area of pedestrians at Soeprapto street, Gorontalo cityit has already been not appropriate with the theory considering within its function and contentment. It was because it was also used for other various activities rather than walking. Pedestrian trackswere actually open area that ought to be used for walking rather than other activities, so that it will not change the behavioral pattern in utilizing the tracks.
\end{abstract}

Keywords: Behavioral mapping, Pedestrian ways, Sector informal

\section{PENDAHUUAN}

Fungsi utama dalam suatu space merupakan fungsi dasar sebagai hasil perancangan, namun karena dalam pelayanannya mempunyai efek negatif dan dapat dimanfaatkan oleh fungsi lain, sehingga muncul fungsi sekunder dari space tersebut. Pergeseran fungsi ruang pedestrian jelas membuat ketidaknyamanan para pejalan kaki. Mereka tidak bisa lagi tenang berjalan sambil menikmati keramaian kota dan nikmatnya berbelanja, mereka harus berhati-hati dan tetap waspada, jangan sampai terserempet kendaraan yang berlalu lalang. Sedangkan bagi sektor informal, ruang pedestrian sebagai lahan yang potensial untuk berdagang. Melihat fenomena tersebut, maka ruang pedestrian mempunyai fungsi yang ganda.

Setelah mengamati secara cepat, sektor informal mewujudkan tempat jualan dengan bangunan atap semi permanen dan mungkin bisa berkembang menjadi permanen karena atap tenda yang digunakan selalu tetap ada. Dampak yang terjadi adalah fungsi ruang pedestrian sebagai fasilitas pejalan kaki menurun, bahkan tidak berfungsi sebagai sarana yang diharapkan. Dampak lain yang ditimbulkan kegiatan aktivitas sektor informal, misalnya sampah, air limbah dan aspek keindahan terganggu, secara visual. Selain sektor informal, pedagang resmipun meletakan barang dagangannya di ruang pedestrian. Selain itu kondisi perkerasan yang tidak memberikan kenyamanan pejalan kaki untuk melaluinya juga menjadi masalah mengingat koridor ini merupakan pusat kota dan pusat pedagangan yang diindikasikan akan banyak pejalan kaki yang menggunakannya.

Dengan latar belakang tersebutlah maka peneliti terdorong untuk melakukan penelitian tentang masalah tersebut diatas.

\section{ISI PENELITIAN}

Lokasi penelitian berada di koridor Jalan Soeprapto Kota Gorontalo. Ruang pedestrian pada koridor ini terjadi privatisasi oleh sektor informal.

\subsection{Metode Penelitian}

Metode yang digunakan adalah metode penelitian perilaku dengan teknik behavioral mapping. Pemetaan perilaku ini dilakukan secara langsung pada saat dan tempat dimana dilakukan pengamatan, menggunakan dengan dua cara pemetaan yaitu : Place Centered Mapping dan Person Centered Mapping.

\subsection{Tahapan Penelitian}

\subsubsection{Place Centered Mapping}

Metode Place Centered Mapping digunakan untuk menganalisis besaran trotoar dan badan jalan yang digunakan oleh aktivitas PKL berdasarkan skala waktu (pagi, siang, sore, dan malam), sehingga dapat diketahui bagaimana pola akti vitas PKL dalam menggunakan ruang. Disamping itu, metode ini juga digunakan untuk menganalisis magnet sirkulasi (tempat-tempat yang menjadi nodes) pada kawasan studi.

Tahap-tahap dalam penelitian ini adalah:

a) Membuat sketsa tempat atau setting, meliputi seluruh unsur fisik yang diperkirakan mempengaruhi perilaku pengguna ruang tersebut.

b) Langkah berikutnya adalah membuat daftar perilaku yang akan diamati. Perilaku laki-laki dan perempuan pada suatu tempat dengan tujuan yang berbeda berdasarkan waktu yang sudah ditentukan. 
c) Mencatat berbagai perilaku dalam tempat tersebut dengan menggambarkan simbol-simbol pada peta dasar yang telah disiapkan.

d) Membuat sketsa terhadap perilaku PKL dalam menggunakan badan jalan dan trotoar tersebut untuk berjualan.

\subsubsection{Person Centered Mapping}

Metode Person Centered Mapping digunakan untuk dimaksudkan untuk menganalisis sirkulasi pejalan kaki pada jam yang sudah ditentukan, sehingga dapat diketahui gangguan-gangguan yang terjadi dalam pergerakan yang disebabkan oleh aktivitas PKL pada badan jalan dan trotoar.

Tahap-tahap dalam penelitian ini adalah :

a) Sketsa dasar area atau setting yang akan diobservasi, terutama bangunan dan aktivitas yang berlangsung.

b) Definisi yang jelas tentang bentuk-bentuk perilaku yang diamati, dihitung dan dideskripsikan serta didiagramkan.

c) Rencana waktu yang jelas pada saat kapan pengamatan akan dilakukan. Pengamatan dilakukan setiap hari (hari biasa dan hari libur) selama satu minggu. Dari pengamatan tersebut maka akan diperoleh waktu yang paling sibuk (peak hours).

d) Mengikuti pergerakan dan aktivitas yang dilakukan oleh orang atau sekelompok orang yang telah dipilih menjadi sample tersebut, untuk mengetahui sirkulasi yang terbentuk pada koridor jalan dan trotoar di kawasan studi

e) Prosedur sistematis yang jelas harus diikuti selama observasi. Berkaitan dengan tujuan penelitian, maka prosedur yang dilakukan meliputi obyek yang diteliti yaitu koridor dan magnit sirkulasi.

\subsubsection{Time Budget Method}

Waktu pengamatan berdasarkan sistem aktifitas yang terjadi dibagi menjadi beberapa periode dengan segmentasi waktu adalah

a) Periode I : Pukul 09.00-12.00 (Pagi-Siang)

b) Periode II : Pukul 13.00-16.00 (Sore)

c) Periode III : Pukul 17.00-20.00 (Malam)

d) Periode IV : Pukul 21.00-24.00 (Malam)

\subsection{Analisis dan Pembahasan}

\subsubsection{Analisis Aktivitas PKL}

Metode analisis pada tahap ini akan menggunakan metode place center map untuk mendapatkan gambaran bagaimana kecenderungan fenomena privatisasi ruang jalan yang terbentuk. Fenomena kecenderungan aktivitas PKL (persebaran privatisasi ruang jalan) di Jl. Soeprapto adalah sebagai berikut:

a) Fenomena privatisasi ruang jalan sebagian besar dilakukan oleh sektor informal, dan diikuti oleh sektor formal sebagai perluasan wilayah dagang ke ruang publik (jalur pedestrian) yang mengubah ruang publik menjadi ruang privat, hal ini disebabkan oleh 3 faktor, yaitu :

- Keberadaan linkage kawasan sebagai ruang pergerakan yang memiliki kepadatan dengan intensitas tinggi memiliki nilai yang cukup strategis untuk fungsi perdagangan dan jasa.

- Fungsi bangunan formal yang didominasi oleh fungsi perdagangan dengan aktivitas jual beli yang tinggi memicu timbulnya sektor informal yang ingin menjangkau daya jual pembeli yang rendah.

- Sektor formal yang melakukan infansi keruang publik memiliki massa yang dominan kecil sehingga membatasi perluasan ruang display.

b) Tidak terjadi perubahan terhadap besaran ruang yang digunakan aktivitas sektor informal maupun formal dalam kegiatan ekspansi/privatisasi ruang pedestrian dan badan jalan setiap harinya. Sektor formal dan informal menempati lokasi yang sama dengan jenis sarana usaha yang digunakan berdasarkan skala waktu.

c) Keberadaan nodes kawasan sebagai pertemuan antara linkage cenderung membentuk konsentrasi privatisasi ruang jalan, Fungsi entrance dan exit kawasan sebagai point masuk dan keluarnya pergerakan kendaraan cenderung dimanfaatkan sektor infromal (PKL) dalam menjangkau pengunjung/pembeli sedekat mungkin.

d) Setting ruang jalan yang kurang memperhatikan sisi fungsional dan estetika sehingga menurunkan image kawasan menjadikan sektor informal (PKL) merasa bebas dalam beraktivitas tanpa memperhatikan estetika.

\subsubsection{Analisis Gangguan Terhadap Sirkulasi Pejalan Kaki}

Selanjutnya yang dilakukan adalah menganalisis gangguan/konflik terhadap sirkulasi pejalan kaki yang terjadi secara lebih detail di tiap penggal dengan menggunakan teknik person centre map.

Adapun aktor-aktor yang menganggu sirkulasi pejalan kaki antara lain:

a. Pejalan kaki

b. Pedagang Kaki Lima (PKL)

c. Pemarkir kendaraan

d. Pengendara bentor (becak motor)

e. Pengunjung PKL

f. Pengunjung toko/bangunan formal

Waktu amatan yang sama yaitu dari pukul 09.00 pagi hingga pukul 24.00 malam. Pemilihan waktu ini berdasarkan pada waktu dimulainya aktivitas dari sektor formal yang diikuti oleh sektor informal (PKL dan parkir) yang menjadi objek dalam penelitian ini hingga berakhirnya aktivitas yang dilakukan. Intensitas waktu amatan pada penelitian ini dilakukan setiap 3 jam sekali untuk mengetahui secara urut kegiatan yang berlangsung di ruang 
publik sehingga didapatkan data perubahan secara detail.

Dari amatan tentang gangguan/konflik pejalan kaki disetiap waktu, dapat disimpulkan bahwa :

a) Gangguan/konflik pejalan kaki sebagai besar terjadi diruang pedestrian, dimana ganggguan dilakukan oleh pedagang kaki lima (PKL) yang melakukan privatisasi ruang, pergerakan pejalan kaki terpaksa terjadi dibadan jalan ketika ruang pedestrian dikuasai sepenuhnya oleh PKL.

b) Keberadaan spasial yang terbatas karena tingkat kepadatan membuat tekanan-tekanan aktivitas informal yang kurang terkontrol di kawasan ini yang notabene bukan bagian dari fungsi utama kawasan.

c) Desakan tidak terkontrol semakin diperparah dengan adanya magnet pertumbuhan yang sangat kuat dikawasan ini, yang pada akhirnya membawa dampak terhadap kualitas keruangan, di mana kualitas keruangan yang terbentuk terkadang membawa beberapa dampak permasalahan, yaitu pertumbuhan fenomena privatisasi ruang jalan oleh sektor informal maupun formal yang tidak terkontrol.

d) Keberadaan PKL dan parkir di ruang publik dipengaruhi oleh aktivitas bangunan formal.

e) Pola pergerakan yang terjadi adalah pola zig-zag. Pola pergerakan dipengaruhi oleh keberadaan PKL diruang pedestrian dan parkir on street di ruang jalan.

f) Waktu puncak terjadinya gangguan/konflik terhadap ruang pedestrian dan ruang jalan oleh setting fisik lapak PKL dan parkir berlangsung diwaktu yang sama yaitu pukul $09.00-12.00$.

g) Waktu terendah terjadinya gangguan/konflik terhadap ruang pedestrian dan ruang jalan oleh setting fisik lapak PKL dan parkir berlangsung diwaktu yang sama yaitu pukul $21.00-24.00$.

\subsubsection{Analisis Hasil Kuesioner}

Tabel 1. Hasil kuesioner penilaian pengunjung terhadap PKL yang berada diruang pedestrian

\begin{tabular}{|c|c|c|c|c|c|c|c|}
\hline \multirow[b]{2}{*}{ No } & \multirow{2}{*}{ Aspek negatif } & \multicolumn{5}{|c|}{ Nilai } & \multirow{2}{*}{ Aspek positif } \\
\hline & & -2 & -1 & 0 & 1 & 2 & \\
\hline 1 & $\begin{array}{c}\text { Sempit/ sesalk } \\
\text { berjalan }\end{array}$ & 13 & 60 & & 27 & & Leluasa berjalan \\
\hline 2 & Jenuh ketika berjalan & & 27 & 13 & 60 & & $\begin{array}{l}\text { Senang ketika } \\
\text { berjalan }\end{array}$ \\
\hline 3 & $\begin{array}{l}\text { Tegang ketika } \\
\text { berjalan }\end{array}$ & & 27 & 7 & 67 & & $\begin{array}{c}\text { Tenang ketika } \\
\text { berjalan }\end{array}$ \\
\hline 4 & $\begin{array}{c}\text { Tidak aman ketika } \\
\text { berjalan }\end{array}$ & & 7 & 20 & 53 & 20 & Aman ketika bejalan \\
\hline 5 & $\begin{array}{l}\text { Tdk Mengundang } \\
\text { untuk berjalan }\end{array}$ & & 20 & 13 & 67 & & $\begin{array}{c}\text { Mengundang untuk } \\
\text { berjalan }\end{array}$ \\
\hline 6 & PKL tidak tertata & 20 & 20 & 13 & 47 & & PKL yang tertata rapi \\
\hline 7 & $\begin{array}{l}\text { Bentuk PKI yang } \\
\text { jelek }\end{array}$ & 27 & 27 & 20 & 27 & & $\begin{array}{l}\text { Bentuk PKL yang } \\
\text { indah }\end{array}$ \\
\hline 8 & $\begin{array}{c}\text { Tidak selaras dengan } \\
\text { bangunan }\end{array}$ & 7 & 33 & 13 & 47 & & $\begin{array}{c}\text { Selaras dengan } \\
\text { bangunan }\end{array}$ \\
\hline 9 & $\begin{array}{l}\text { Lapak PKL yang } \\
\text { kotor }\end{array}$ & 13 & 53 & & 33 & & $\begin{array}{l}\text { Lapak PKL yang } \\
\text { bersih }\end{array}$ \\
\hline 10 & $\begin{array}{l}\text { Tidal dominan } \\
\text { terhadap trotoar }\end{array}$ & 7 & 47 & & 47 & & $\begin{array}{c}\text { Dominan terhadap } \\
\text { trotoar }\end{array}$ \\
\hline
\end{tabular}

Analisis hasil kuesioner yang telah dibagikan kepada responden, ini untuk mengetahui pendapat pengunjung tentang kondisi ruang pedestrian dan badan jalan dengan adanya PKL. Persebaran kuesioner dilakukan kepada pengunjung ruang publik untuk menyerap pendapat dan informasi yang bersifat subjektif. Seluruh kawasan studi disebarkan 45 kuesioner untuk mewakili setiap kelompok aktivitas di ruang terbuka publik. Dalam persebaran kuesioner dengan mengambil sampel person terhadap pengunjung kawasan perdagangan.

Pembahasan tabel penilaian pengunjung terhadap PKL yang berada diruang pedestrian:

\section{a. Untuk rasa/kesan ketika menggunakan ruang pedestrian}

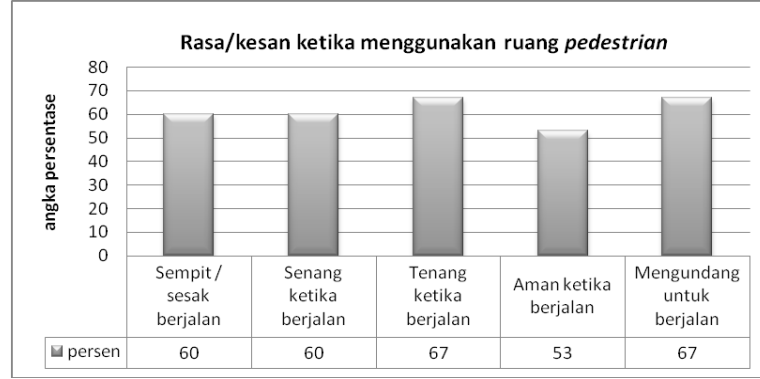

Gambar 1. Diagram hasil kuesioner rasa/kesan pengunjung ketika menggunakan ruang pedestrian

Dari Tabel 1 dan Gambar 1 dapat dilihat bahwa responden merasakan sempit/sesak berjalan ketika menggunakan ruang pedestrian dengan jumlah responden yang memilih sebesar $60 \%$, sedangkan sebesar $27 \%$ merasakan leluasa bergerak ketika berjalan. Sebesar $60 \%$ merasakan senang ketika berjalan, hal ini dikarenakan lapak PKL bisa memunculkan karakter karena ada keragaman dalam bentuk PKL namun sebesar $27 \%$ ) merasakan jenuh ketika berjalan diruang pedestrian, hal ini menandakan perbedaan yang cukup besar antara responden senang - jenuh.

Responden merasakan tenang ketika menggunakan ruang pedestrian dengan persentase sebesar $67 \%$, hal ini dikarenakan tidak adanya interaksi antara pejalan kaki dengan kendaraan dan sebesar $27 \%$ merasakan tegang ketika berjalan. Sedangkan dari sisi keamanan, sebesar $53 \%$ responden merasa aman ketika menggunakan ruang pedestrian dan hanya sebesar $7 \%$ responden merasakan tidak aman ketika berjalan.

Responden merasakan bahwa jalur pedestrian yang ada dikawasan mengundang untuk berjalan dengan persentase sebesar $67 \%$, sedangkan persentase sebesar $20 \%$ merasakan bahwa jalur pedestrian tidak mengundang untuk berjalan. 


\section{b. Untuk bentuk PKL diruang pedestrian}

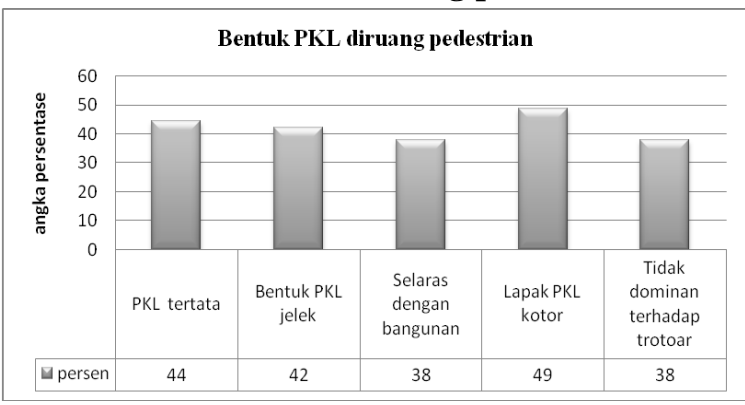

Gambar 2. Diagram hasil kuesioner penilaian bentuk PKL diruang pedestrian

Dari Gambar 2 dapat dilihat bahwa responden merasakan PKL diruang pedestrian cenderung tertata dengan jumlah persentase sebesar $47 \%$ sedangkan sebesar $20 \%$ memilih PKL tidak tertata denga rapi. Namun dari sisi bentuk, sebesar $27 \%$ memilih bentuk PKL sangat jelek dan sebesar $27 \%$ memilih bentuk PKL yang jelek.

Responden menilai bahwa setting PKL diruang pedestrian selaras dengan bangunan formal dengan persentase sebesar $47 \%$ dan yang memilih sangat tidak selaras sebesar $33 \%$, menurut pengamatan dilapangan memang setting PKL diruang pedestrian dibuat sesuai dengan semaunya pedagang tapi tetap memperhatikan keselarasan dengan bangunna dibelakang/depannya. Responden menilai bahwa kebanyakan PKL sering meninggalkan sampah sehingga dari tingkat kebersihan sebesar $53 \%$ responden memilih lapak PKL yang kotor.

Responden menilai bahwa setting PKL tidak dominan terhadap jalur pedestrian dengan jumlah responden sebesar $47 \%$ namun responden menilai PKL dominan terhadap jalur pedestrian dengan jumlah yang sama yaitu $47 \%$, ini dikarenakan setting PKL dikawasan penelitian terdiri dari dua teritori yaitu teritori primer dan teritori sekunder namun sebagian besarnya adalah teritori sekunder dimana masih menyisahkan sebagian ruang pedestrian untuk pejalan kaki.

\subsection{Hasil}

Fenomena privatisasi ruang jalan sebagian besar dilakukan oleh sektor informal dan diikuti oleh sektor formal sebagai perluasan wilayah dagang ke ruang publik (jalur pedestrian) yang mengubah ruang publik menjadi ruang privat, hal ini disebabkan oleh 5 faktor, yaitu :

1. Keberadaan linkage kawasan sebagai ruang pergerakan yang memiliki kepadatan dengan intensitas tinggi memiliki nilai yang cukup strategis untuk fungsi perdagangan dan jasa.

2. Fungsi bangunan formal yang didominasi oleh fungsi perdagangan dengan aktivitas jual beli yang tinggi memicu timbulnya sektor informal yang ingin menjangkau daya jual pembeli yang rendah.
3. Sektor formal yang melakukan infansi keruang publik memiliki massa yang dominan kecil sehingga membatasi perluasan ruang display.

4. Jarak dan aksesibilitas, dimana tingkat kemudahan pencapaian antar linkage mempengaruhi tingkat pertumbuhan PKL serta jarak tempu yang terjangkau bagi pejalan kaki.

5. Adanya ruang jalan yang tersedia cukup luas memicu parkir on street (sektor informal).

\section{KESIMPULAN}

Pada dasarnya tidak terjadi perubahan terhadap besaran ruang yang digunakan aktivitas sektor informal maupun formal dalam kegiatan ekspansi/privatisasi ruang pedestrian dan badan jalan setiap harinya. Sektor formal dan informal menempati lokasi yang sama dengan jenis sarana usaha yang digunakan berdasarkan skala waktu. Keberadaan nodes kawasan sebagai pertemuan antara linkage cenderung membentuk konsentrasi privatisasi ruang jalan, dimana nodes menjadi starting konsentrasi privatisasi dan dilanjutkan privatisasi secara linear dengan mengikuti elemen ruang jalan (ruang pedestrian). Terjadi kecenderungan pengurangan aktivitas privatisasi ketika menjauh dari nodes kawasan.

Pentingnya jalur pedestrian yang bebas dari privatisasi sektor informal pada sebuah area perdagangan dapat menjadi suatu hal yang signifikan yang harus dipikirkan oleh pemerintah kota. Sebuah kawasan perdagangan dengan aktivitas jual beli tinggi ini merupakan area yang padat dengan sirkulasi penggunanya. Banyaknya arus pejalan kaki baik menuju ke kawasan perdagangan maupun dari kawasan perdagangan menuju ke area luar memberikan dampak yang cukup berarti bagi pemenuhan kebutuhan akan fasilitas pejalan kaki.

Perencanaan dengan menerapkan konsep full pedestrian mall terhadap koridor jalan ini merupakan alternatif pemecahan masalah yang cukup tepat mengingat sudah semerawutnya ruang publik ini dengan aktivitas informal.

Konsep pedestrian mall merupakan konsep penataan kawasan pusat kota khususnya pada pusat perdagangan, agar dapat meningkatkan daya tarik pusat kota dari segi sosial-ekonomi, fasilitas yang disediakan dan status sosialnya. Hal yang menonjol dari konsep pedestrian mall ini adalah penataan kawasan yang mengutamakan pejalan kaki pada suatu kawasan berbelanja dengan suasana rekreatif, aman, dan nyaman (Mulyati, 2009).

Konsep pedestrian mall diciptakan dengan cara menutup ruas jalan yang semula digunakan oleh lalu lintas kendaraan bermotor. Ruas jalan tersebut kemudian ditingkatkan kualitasnya dengan cara memasang pelapis jalan, memasang lampu, membuat lanscape, dan melengkapi dengan street furniture. Pejalan kaki diprioritaskan lebih tinggi dibanding kendaraan bermotor, bisa dibilang area 
bebas kendaraan bermotor kecuali darurat. Bongkar muat / loading-unloading untuk petokoan diatur pada jam-jam tertentu. Lapak sektor informal tidak digusur sepenuhnya, tapi dipindahkan ketengah ruang jalan.

\section{DAFTAR PUSTAKA}

- Carr, Stepen, 1992, Public Space, Cambrige University Press. New York.

- Lala, Sugi Hendi dan Andjar Widajanti, 2015, Persepsi Pejalan Kaki Terhadap Kenyamanan Jalur Pedestrian, Jurnal Universitas Mercubuana Jakarta.

- Listianto, Terstiervy Indra Pawaka, 2006, Hubungan Fungsi dan Kenyamanan Jalur Pedestrian, Tesis Jurusan Arsitektur Universitas Diponegoro.

- Lynch, Kevin, 1980, The Image of The City, MIT Press, Cambridge, MA.

- Mauliani, Lily dan Ari Widyati Purwantiasning, Wafirul Aqli, 2012, Kajian Jalur Pedestrian Sebagai Ruang Terbuka Pada Area Kampus, Jurnal Universitas Muhammadiyah Jakarta.

- Mulyati, Ahda dan Fitria Junaeny, 2009, Pusat Pertokoan Dengan Konsep Pedestrian Mall di Kota Palu, Jurnal "Ruang" Vol. 1 No. 1 Edisi September 2009, Jurusan Arsitektur Fakultas Teknik Uni versitas Tadulako.

- Shirvani, Hamid, 1985, The Urban Design Process, Van Nostrand Reinhold company, Inc, New York.

- Surya, Vincentia Reni Vita dan Haryadi, Jatmika, 2008, Faktor -Faktor Yang Mempengaruhi Hubungan Aktivitas Formal dan Aktivitas Informal di Ruang Jalan Jenderal Sudirman, Salatiga, Jurnal Arsitektur dan Perencanaan Vol. 3 No. 1 Edisi Oktober 2008, Universitas Gadjah Mada.

- Widyaningrum, 2001, Jalur Pejalan Kaki di Kawasan Ruang Publik, Tesis Jurusan Arsitektur Universitas Diponegoro. 